\title{
Investment Strategy on the Zagreb Stock Exchange Based on Dynamic DEA
}

\section{Tihana Škrinjarić}

University of Zagreb, Faculty of Economics and Business, Croatia tskrinjaric@efzg.hr
CroEconSur

Vol. 16

No. 1

April 2014

pp. $129-160$

Received: November 1, 2013

Accepted: March 21, 2014

Research Article

doi:10.15179/ces.16.1.5

\section{Abstract}

Nowadays, there is a growing interest in the application of quantitative methods in portfolio management, as the results of their application can be used as guidelines for managing a successful investment portfolio, i.e., a portfolio that outperforms the market. This paper deals with the Data Envelopment Analysis (DEA) approach and a Dynamic Slacks-Based Measure as a method of forming a portfolio which would predominantly outperform the market. In order to test the strategy, data on stocks listed on the Zagreb Stock Exchange were gathered for the period April 2009 - June 2012. Using the quarterly returns, standard deviations and coefficients of skewness as links, a dynamic slacks-based measure approach was applied to evaluate the relative efficiency of stocks in each quarter. The findings indicate that a portfolio based on the results of the optimization beats the market in terms of both returns and risk. This is the first implementation of 
the dynamic DEA model in stock trading. The results suggest that it is superior to basic DEA models.

Keywords: Dynamic Slacks-Based Measure (DSBM), Data Envelopment Analysis (DEA), portfolio, stock market, Zagreb Stock Exchange

JEL classification: C14, C61, G11

\section{Introduction}

There are a lot of different methods and models which are aimed at searching for the portfolio which could beat the stock market. ${ }^{1}$ There is also a growing need for the implementation of techniques that might improve the performance of an investment portfolio. Modern portfolio theory (MPT) suggests that by analyzing the stock markets, investors focus on the expected return and risk of each stock. Investors seek for the biggest return possible while they aim to minimize the risk. The most famous result is given in the form of the Markowitz model (1952) that relies on the assumption that stock returns follow normal distributions. However, in the last couple of decades, theory has proved and empirical analyses have confirmed that investors make their decisions based upon the third moments of stock return distributions as well (Mandelbrot, 1963; Fama, 1965). In that way, new portfolio models have emerged (Graddy and Homaifar, 1988; Jondeau and Rockinger, 2003; Athayde and Flores, 2004; Adcock, 2005). These models incorporate stock return, risk and skewness in order to find optimal portfolio structure.

Due to the growing number of different optimization techniques and fields in operations research, there has been an explosion of various models ${ }^{2}$ evaluating the performance of almost every aspect of an economy. This paper uses Data

1 Mathematical models and tools such as the Markowitz model (1952), multi-criteria modeling, Data Envelopment Analysis, statistical and econometric models and methods (regression, ARIMA models, GARCH models, VAR models, etc.). Additionally, fundamental and technical analyses are also popular in the field of stock investing.

2 Linear and non-linear programing, transportation and assignment problems, network optimization models, Markov chains methodology, many Data Envelopment Analysis models, etc. 
Envelopment Analysis (DEA) as a method for measuring the relative efficiency ${ }^{3}$ of stocks listed on the Zagreb Stock Exchange. Data Envelopment Analysis is a relatively new field of operations research which models and evaluates the relative efficiency of decision-making units. Data on stock return, risk and skewness are employed in order to find the most efficient portfolio in terms of stock selection and allocation.

The Croatian stock market was developing rapidly until the 2008 crisis that struck the global financial markets. From 2002 to 2013 total turnover increased over 1,776,756 times, trading volume increased over 64 times, total number of transactions increased over 1,003,568 times and market capitalization increased over 5 times (ZSE, 2001; 2014). Ever since the crisis started, investors have become very careful not only when investing in stocks, but also in currencies, bonds, etc. Obviously, there is a need for a strategy which could ensure the best possible employment of their limited resources. This paper investigates the assessment of a non-parametric method of evaluating the relative efficiency of selected stocks on the Zagreb Stock Exchange and uses these results to form a portfolio whose aim is "to beat the market". If this proves possible, the dynamic slacks-based measure (DSBM) can be confirmed as a useful tool in forming efficient stock portfolios. Moreover, an additional purpose of the paper is to contribute to the scarce research of stock markets in Croatia using Data Envelopment Analysis. ${ }^{4}$

The paper is structured as follows. Section 2 describes previous research regarding the Croatian stock market. Section 3 deals with the methodology, namely, the dynamic slacks-based measure of evaluating the efficiency of decision-making units. In the fourth section, a description of data is given, as well as the results of the analysis. The final section concludes the paper with recommendations.

3 Throughout the paper, when the term efficiency is mentioned, it refers to the relative efficiency within DEA terminology.

4 This study is the first one to employ a more complex and a realistic approach to modeling by applying the dynamic DEA model compared to the basic static models applied in the literature so far. 


\section{Previous Research in Croatia}

As already mentioned, Croatian literature using DEA methodology is rather scarce. Some authors have used econometric techniques to analyze the cointegration of the Croatian stock market and the reactions of the stock market to shocks in macroeconomic variables (Vizek and Dadić, 2006; Barbić and Čondić-Jurkić, 2011; Benazić, 2008; Hsing, 2011). Others have applied optimization techniques in order to find optimal portfolio structure in terms of portfolio theory and the Markowitz model (Briš, Kristek and Mijoč, 2008; Fabac and Munđar, 2011; Jakšić, 2007; Jerončić and Aljinović, 2011; Marasović, Poklepović and Aljinović, 2011; Marasović and Šego, 2006; Škrinjarić 2013a). This second group of authors are linked to this study in terms of finding an efficient portfolio which will result in the biggest return possible, given a predetermined level of risk.

The most relevant group of papers upon which this study is based apply DEA models to evaluate stocks on the capital market (Chen, 2008; Powers and McMullen, 2002; Pätäri, Leivo and Honkapuro, 2010; Lopes et al., 2008).5 Chen (2008) analyzes the "size effect" by constructing portfolios of small-size firms on the one hand, and big-size ones on the other, on the Taiwan stock market. Pätäri, Leivo and Honkapuro (2010) use return and several risk measures to construct efficient portfolios for Finland. Powers and McMullen (2002) use return, earnings per share, beta, sigma and other performance measures to identify efficient stocks within a large dataset of American and British stocks. Lopes et al. (2008) analyze the Brazilian stock market by employing a DEA model on stocks included in the IBrX-100 index. Gardijan and Kojić (2012) were the first to examine the Croatian stock market. They used return and several risk measures to construct a DEA-efficient portfolio. They have shown that such a portfolio beats the market approximately 50 percent of the time. Most of the above-mentioned papers resulted in DEA portfolios which were superior compared to the official stock market index.

5 Gardijan and Kojić (2012) is the only paper in the Croatian literature that belongs to this group. 
Based on this final group of papers, some conclusions can be made. First, DEA models as a tool for evaluating stocks and financial assets have been applied only during the last decade. Second, only a few papers deal with stocks. All of them use the simplest models to evaluate stock performance. More specifically, they use BCC (Banker-Cooper-Rhodes) and/or CCR (Charnes-Cooper-Rhodes) models - the two most common and basic ones that use average values of inputs and outputs for the whole analyzed period.

The model applied in this paper goes beyond that by incorporating time changes of (relative) efficiency. In that way it contributes to the field of Data Envelopment Analysis of the stock market by introducing a more realistic assumption: that the relative efficiency of stocks changes over time. Consequently, investors can rebalance their portfolios in each period in order to achieve a portfolio structure which will beat the market. The theoretical models used in this study were developed in 2010. Therefore, there has been only one application so far and it refers to education economics (Costa, Ramos and Souza, 2012).

\section{Methodology - Dynamic Slacks-Based Measure (DSBM)}

Data Envelopment Analysis is a set of non-parametric methods and models in mathematical programing whose purpose is to evaluate the efficiency of different units of observation. The common term given to these units is decision-making units (DMUs). Each DMU uses one or more inputs to produce one or more outputs and the data on inputs and outputs of each DMU are used to evaluate the relative performance, i.e., the efficiency of an individual DMU compared to the other DMUs. ${ }^{6}$ Some of the advantages of this approach lie in the comparison

6 The founders of this field of operations research are Charnes, Cooper and Rhodes (1978), but the interest in DEA models has significantly increased in the past couple of years in different areas of both academic and practical study. Using this approach, the performance of a decision-making unit can be analyzed from different aspects in order to enhance its future results. However, the decision-making unit does not have to be a production unit (firms). 
of all the DMUs to the best (most efficient) one and not to the average one; ${ }^{7}$ it can also identify the sources of inefficiency of each DMU, etc. On the other hand, there are some disadvantages: the results are sensitive to outliers, ${ }^{8}$ the exclusion of important input or output variables can lead to biased results, etc.

For a number of years authors have been evaluating hospitals, hotels, counties, countries, etc. (Cooper, Seiford and Zhu, 2004), while stocks have come into the spotlight of researchers just recently. In Croatia, only a few authors have dealt with DEA methods and models in order to measure the efficiency of the banking sector (Neralić, 1996), health care (Rabar, 2010), trade sector (Šegota, 2008), stock market (Gardijan and Kojić, 2012) etc., by using two of the most popular models of DEA, the CCR (Charnes-Cooper-Rhodes) and BCC (BankerCharnes-Cooper) models. These models are relatively simple and refer to one time period. When evaluating stock performance, looking at a single period or calculating the average for more periods is misleading (and in a way incorrect) due to the high volatility of prices on stock markets. For example, if in one year a stock realizes a loss of 15 percent and in the other year it realizes a return of 17 percent, it has a positive return of 1 percent on average. By considering only data averages, it is not clear what has actually happened in each year. That leads us to take into account efficiency changes over time. Consequently, we will apply a dynamic DEA model, which overcomes the problems of averaging data and the problems of permanent changes on stock markets. In DEA, the measurement of intertemporal efficiency changes has been in the spotlight for a long time. The pioneers in this field are Klopp (1985), Färe et al. (1994) and Färe and Grosskopf (1996). In 2010, Tone and Tsutsui (2010) developed a dynamic slacks-based measure of efficiency that measures the efficiency changes over time by incorporating carry-over activities (links) which provide the measurement of a period-specific efficiency. Another advantage of the model is the non-radial characteristic, which treats each input and output individually. Moreover, in

7 When compared to econometric methods such as linear regression, regression compares all of the observations to the average one.

8 Other mathematical and statistical methods are sensitive as well. 
evaluating an individual decision-making unit, the changes of inputs and/or outputs do not have to be proportional. Tone and Tsutsui have identified four types of carry-overs (links): desirable (good), undesirable (bad), discretionary and non-discretionary. In that way, specific demands of researchers can be incorporated in the model. Good links refer to desirable carry-overs (e.g., retained earnings of firms, coefficient of asymmetry of stock return), bad links refer to undesirable carry-overs (e.g., loss carried forward), discretionary links are carryovers that decision-making units can handle freely," and non-discretionary links are carry-overs which the decision-making unit cannot control. The basic idea of a dynamic slacks-based measure is given in Figure 1.

Figure 1: Dynamic Structure

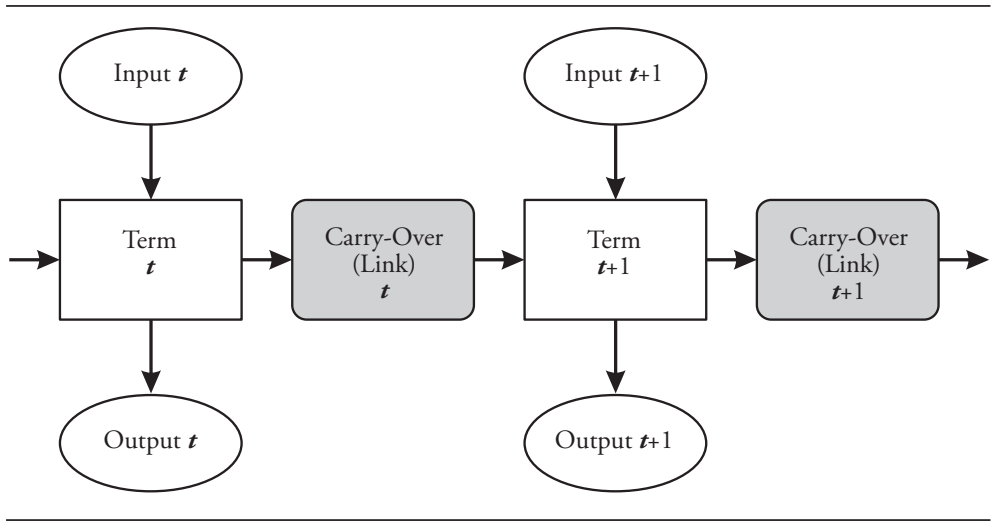

Source: Tone and Tsutsui (2010: 146).

The observed decision-making unit uses inputs to produce outputs in time period (term) $t$. In this process, carry-overs are present in each time period. The carry-over from the term $t$ affects the production process in term $t+1$. In term $t+1$ the decision-making unit again uses inputs to produce outputs, and again the process continues. In order to relate this method to stock selection, we can compare the DMU with an ordinary stock. In each period, investors calculate

9 Since we are focusing on stocks as DMUs, individual stocks cannot freely handle links. 
expected returns which they aim to maximize (output), expected risk which they aim to minimize (input) and other relevant measures. Portfolio theory suggests that investors seek to maximize the portfolio skewness because it is related to increased occurrence of above-average returns. In that way the portfolio skewness is considered a good link in the model.

The mathematical formulation of this model is as follows. Let us assume we are dealing with panel data on $n$ DMUs $(j=1, \ldots, n)$ during $T$ time periods, $t=1, \ldots, \mathrm{T}$. In each period DMUs use $m$ inputs $(i=1, \ldots, m)$ and $p$ non-discretionary inputs $(i=1, \ldots, p)$ to produce $s$ outputs $(i=1, \ldots, s)$ and $r$ non-discretionary outputs $(i=1, \ldots, r)$. A DMU $j$ at term $t$ is represented by inputs $x_{i j t}(i=1, \ldots, m)$ non-discretionary inputs $x_{i j t}^{\text {fixo }}(i=1, \ldots, p)$, outputs $y_{i j t}(i=1, \ldots, s)$ and non-discretionary outputs $y_{i j t}^{f i x o}(i=1, \ldots, r) .{ }^{10}$ The links (carry-overs) can be categorized into four groups: $z^{\text {good }}$, $z^{\text {free }}, z^{\text {bad }}, z^{f i x}$. For example, notation $z_{i j t}^{\text {bad }}(i=1, \ldots, n b a d ; j=1, \ldots, n ; t=2, \ldots, T)$ denotes all observed bad links up to the term $T$. Now, we can define the production possibilities $\left\{x^{i t}\right\},\left\{x_{i t}^{f i x}\right\},\left\{y^{i t}\right\},\left\{y_{i j}^{f i x}\right\},\left\{z_{i t}^{\text {good }}\right\},\left\{z_{i t}^{\text {bad }}\right\},\left\{z_{i t}^{\text {free }}\right\}$ and $\left\{z_{i t}^{\text {fix }}\right\}$ by

$$
\begin{aligned}
& x_{i t} \geq \sum_{j=1}^{n} x_{i j t} \lambda_{j}^{t} \quad(i=1, \ldots, m ; t=1, \ldots, T), \\
& x_{i t}^{f i x}=\sum_{j=1}^{n} x_{i j t}^{f i x} \lambda_{j}^{t} \quad(i=1, \ldots, p ; t=1, \ldots, T), \\
& y_{i t} \leq \sum_{j=1}^{n} y_{i j t} \lambda_{j}^{t} \quad(i=1, \ldots, s ; t=1, \ldots, T), \\
& y_{i t}^{\text {fix }}=\sum_{j=1}^{n} y_{i j t}^{\text {fix }} \lambda_{j}^{t} \quad(i=1, \ldots, r ; t=1, \ldots, T), \\
& z_{i t}^{\text {good }} \leq \sum_{j=1}^{n} z_{i j t}^{\text {good }} \lambda_{j}^{t} \quad(i=1, \ldots, n g o o d ; t=1, \ldots, T), \\
& z_{i t}^{\text {bad }} \geq \sum_{j=1}^{n} z_{i j t}^{\text {bad }} \lambda_{j}^{t} \quad(i=1, \ldots, \text { nbad } ; t=1, \ldots, T),
\end{aligned}
$$

10 Stocks in this study are DMUs, which "produce" expected returns as outputs, by using risk as inputs. The selection is based on MPT. 
$z_{i t}^{\text {free }}:$ free $(i=1, \ldots$, nfree; $t=1, \ldots, T)$,

$z_{i t}^{f i x}=\sum_{j=1}^{n} z_{i j t}^{f i x} \lambda_{j}^{t}(i=1, \ldots, n f i x ; t=1, \ldots, T)$,

$\lambda_{j}^{t} \geq 0(j=1, \ldots, n ; t=1, \ldots, T)$

$\sum_{j=1}^{n} \lambda_{j}^{t}=1(t=1, \ldots, T)$

where $\lambda^{t} \in R^{n}(t=1, \ldots n)$ is the intensity vector for each term $t$, and $n f i x, n b a d$, ngood and nfree are numbers of fixed, bad, good and free links, respectively. If we assume constant returns to scale, we can omit the last constraint. The condition

$\sum_{j=1}^{n} z_{i j t}^{\alpha} \lambda_{j}^{t}=\sum_{j=1}^{n} z_{i j t}^{\alpha} \lambda_{j}^{t+1} \quad(\forall i ; t=1, \ldots, T-1)$

guarantees the continuity of link flows between time period $t$ and $t+1$. Symbol $\alpha$ stands for free, fix, bad or good links. Now, we can express the $\operatorname{DMU}_{o}(o=1, \ldots, n):{ }^{11}$

$$
\begin{aligned}
& x_{i o t}=\sum_{j=1}^{n} x_{i j t} \lambda_{j}^{t}+s_{i t}^{-}(i=1, \ldots, m ; t=1, \ldots, T), \\
& x_{i o t}^{f i x}=\sum_{j=1}^{n} x_{i j t}^{f i x} \lambda_{j}^{t} \quad(i=1, \ldots, p ; t=1, \ldots, T), \\
& y_{i o t}=\sum_{j=1}^{n} y_{i j t} \lambda_{j}^{t}-s_{i t}^{+} \quad(i=1, \ldots, s ; t=1, \ldots, T), \\
& y_{i o t}^{f i x}=\sum_{j=1}^{n} x_{i j t}^{f i x} \lambda_{j}^{t} \quad(i=1, \ldots, r ; t=1, \ldots, T),
\end{aligned}
$$

11 Basically, each stock analyzed in this study is a DMU, given by relations (12)-(21). Relation (12) describes the risk in each period, (14) return and (16) the good link - skewness. In this study, relations (13), (15), (17)-(19) are omitted as there was no need to include fixed inputs. 
$z_{\text {iot }}^{\text {good }}=\sum_{j=1}^{n} z_{i j t}^{\text {good }} \lambda_{j}^{t}-s_{i t}^{\text {good }}(i=1, \ldots, n g o o d ; t=1, \ldots, T)$,

$z_{i o t}^{\text {bad }}=\sum_{j=1}^{n} z_{i j t}^{\text {bad }} \lambda_{j}^{t}+s_{i t}^{\text {bad }} \quad(i=1, \ldots, n b a d ; t=1, \ldots, T)$,

$z_{\text {iot }}^{\text {free }}=\sum_{j=1}^{n} z_{i j t}^{\text {free }} \lambda_{j}^{t}+s_{i t}^{\text {free }}(i=1, \ldots$, nfree $; t=1, \ldots, T)$,

$z_{i o t}^{f i x}=\sum_{j=1}^{n} z_{i j t}^{f i x} \lambda_{j}^{t} \quad(i=1, \ldots, n f i x ; t=1, \ldots, T)$,

$\sum_{j=1}^{n} \lambda_{j}^{t}=1(t=1, \ldots, T)$,

$\lambda_{j}^{t} \geq 0, s_{i t}^{-} \geq 0, s_{i t}^{+} \geq 0, s_{i t}^{\text {good }} \geq 0, s_{i t}^{\text {bad }} \geq 0$, and $s_{i t}^{\text {free }}:$ free $(\forall i, t)$.

$s_{i t}^{-}, s_{i t}^{+}, s_{i t}^{\text {good }}, s_{i t}^{\text {bad }}$ and $s_{i t}^{\text {free }}$ are slack variables: input excess, output deficit, link deficit, link excess and link deviation, respectively. In order to evaluate the overall efficiency of a $\operatorname{DMU}_{o}(o=1, \ldots, n)$ with variables $\left\{\lambda^{t}\right\},\left\{s_{t}^{-}\right\},\left\{s_{t}^{+}\right\},\left\{s_{t}^{\text {good }}\right\}$, $\left\{s_{t}^{b a d}\right\},\left\{s_{t}^{\text {free }}\right\}$, an input-oriented, output-oriented or non-oriented model can be used, assuming either constant or variable returns to scale. In the input-oriented model, for example, the input-oriented overall efficiency $\theta_{o}^{*}$ is defined as:

$\theta_{t}^{*}=\min \frac{1}{T} \sum_{t=1}^{T} w^{t}\left[1-\frac{1}{m+n b a d}\left(\sum_{i=1}^{m} \frac{w_{i}^{-} s_{i t}^{-}}{x_{i o t}}+\sum_{i=1}^{n b a d} \frac{s_{i t}^{\text {bad }}}{z_{i o t}^{\text {bad }}}\right)\right]$,

subject to (11) and (12) where (22) is the weighted average of given term efficiencies over all observed terms, $\theta_{t}{ }^{*} \in[0,1]$. The more efficient the DMU is, the closer $\theta_{t}{ }^{*}$ (22) is to $1 . w_{i}^{-}$and $w_{i}^{+}$are weights given to term $t$ and input $i$. The researcher can freely define these weights, with respect to:

$\sum_{t=1}^{T} w^{t}=T$ and $\sum_{t=1}^{m} w_{i}^{-}=m \cdot{ }^{12}$

12 The investor can choose freely which input or output is more important in the model, the choice depends upon his/her preferences. 
When an optimal solution in (22) is found, subject to (11) and (12), it is denoted with $\left(\left\{\lambda_{o}^{t^{*}},\left\{s_{o t}^{-*}\right\},\left\{s_{o t}^{+*}\right\},\left\{s_{o t}^{\text {good }}\right\},\left\{s_{o t}^{\text {bad }}\right\},\left\{s_{o t}^{\text {free }}\right\}\right)\right.$, and the input-oriented term efficiency is defined by $\theta_{o t}{ }^{*}$ :

$$
\theta_{o t}{ }^{*}=1-\frac{1}{m+n b a d}\left(\sum_{i=1}^{m} \frac{w_{i}^{-} s_{i o t}^{-*}}{x_{i o t}}+\sum_{i=1}^{n b a d} \frac{s_{i o t}^{b a d^{*}}}{z_{\text {iot }}^{\text {bad }}}\right), t=1, \ldots, T .
$$

The efficiency of the whole period observed is the weighted average of the term efficiencies $\theta_{o t}{ }^{*}$ :

$\theta_{o}^{*}=\frac{1}{T} \sum_{t=1}^{T} w_{t} \theta_{o t}^{*}$

Finally, the definition of the input-oriented overall efficient $\mathrm{DMU}_{o}$ is given as follows. If $\theta_{o}^{*}=1$, a $\mathrm{DMU}_{o}$ is input-oriented overall efficient. This means that $s_{i o t}^{-*}=0, \forall i$, and $s_{i o t}^{b a d^{*}}=0, \forall i$, for all optimal solutions of (22). ${ }^{13}$ The uniqueness of the result is also an issue in these models. Tone and Tsutusi (2010) recommend examining averages of the relative gap between the maximum and minimum of the term efficiencies and links calculated:

$$
\frac{\max -\min }{\max }
$$

If the relative gap is small, minor deviations in both term efficiencies and links can be neglected, as can the multiple optima.

\section{Data Description and Empirical Results}

Monthly data on prices for 26 stocks were obtained from the Zagreb Stock Exchange (2012) for the period from April 2009 to June 2012. Twenty-six stocks were chosen for the sample because of the data availability. Namely, only 26 stocks were traded during each month in the analyzed period. Model inputs,

13 Further discussion of output-oriented and non-oriented models and definitions can be found in Tone and Tsutsui (2010). 
outputs and links have to be defined. First, monthly returns were calculated, based on the following formula:

$$
R_{i t}=\ln \left(\frac{P_{i t}}{P_{i t-1}}\right),
$$

where $R_{i t}$ denotes return on stock $i$ in month $t, P_{i t}$ denotes the price of stock $i$ in month $t, P_{i t-1}$ denotes the price of stock $i$ in month $t-1$ and $l n$ denotes the natural logarithm.

Since standard deviation and coefficient of skewness do not exist for monthly data, observations need to be recalculated on a quarterly basis. The standard deviation could be calculated on a two-month basis (see Equation (28)), but since the coefficient of skewness needs at least three values (see Equation (29)), both returns and risk were calculated on a quarterly basis. Quarterly returns were approximated as an average of each three months. For example, the first quarterly return is based on monthly returns from April to July 2009. Quarterly standard deviations and the coefficient of skewness were calculated as follows:

$$
\sigma_{i t}=\sqrt{\frac{\sum_{i=1}^{\tau}\left(R_{i t}-\bar{R}_{i}\right)}{\tau-1}}
$$

and

$$
\alpha_{3, i t}=\frac{\tau}{(\tau-1)(\tau-2)} \sum_{i=1}^{\tau}\left(\frac{R_{i t}-\bar{R}_{i}}{\sigma_{i}}\right)^{3},
$$

where $\sigma_{i t}$ denotes the standard deviation of return of stock $i$ in quarter $t, \tau$ denotes the number of periods used to calculate the individual statistic and $\alpha_{3, i t}$ denotes the coefficient of skewness of return of stock $i$ in quarter $t$. Finally, the sample consists of data on returns, standard deviation and the coefficient of skewness for 13 quarters for each of the 26 stocks. 
Since investors focus on the biggest stock returns they can achieve, the data on returns are used as an output in the model. On the other hand, the data on standard deviation, as a measure of risk, are used as an input. The coefficient of skewness is used as a good link in the model because this measure gives information on the distribution of the returns of each stock. For $\alpha_{3, i t}>0$, the distribution is positively skewed, which means that returns greater than the average (or positive returns if we look at centered data) are more likely to occur. The assumption is that investors are aiming for stocks whose return distribution will be characterized rather by positive than negative skewness. Theoretical justification lies in the development of MPT during the decades: Arditti (1967) explains that investors favor positive skewness of returns, because it decreases the occurrence of extreme negative returns. This is a result of investors' decreasing absolute risk aversion. Alderfer and Bierman (1970) carried out a survey in which they showed that investors prefer positive asymmetry of stock returns, even if it implies smaller expected returns. Maybe the most important contributions were made by Müller and Machina (1987: 351): "An expected utility maximizer with continuous von Neumann-Morgenstern utility function $U($.$) will rank$ probability distributions on the basis of their first $m$ absolute moments if and only if $U($.$) is a polynomial of at most degree m$ ", Samuelson (1970), who analyzed expected utility maximization based on the first three portfolio moments, and Rubinstein (1973), who extended the CAPM (Capital Asset Pricing Model) model by incorporating the skewness and co-skewness of stock returns. Even today the stock return asymmetry is important; Athayde and Flores (2004) explain that investors prefer higher values of odd distribution moments (return and asymmetry), while they aim to minimize the even ones (risk).

Before the optimization, a correlation analysis was performed using the input and output variables. Namely, the robustness of the model depends on the correlations between inputs and outputs (the aim is to achieve higher values of the coefficient of correlation between inputs and outputs), and on the correlations between inputs themselves, as well as outputs (the aim is to have 
low correlated inputs, as well as outputs). This study uses only one input and one output so the correlation was calculated between the return and risk. The value of the coefficient is equal to 0.63 , which indicates a positive medium intensity of correlation..$^{14}$ Thus, the rest of the analysis can be performed. Six variants of the model were optimized for the period 2Q2009 - 1Q2012 (input-oriented, output-oriented and non-oriented, each assuming constant or variable returns to scale) using DEA Solver 7.0. In order to choose the best model, the relative gap between the maximum and minimum of the term efficiencies and links was obtained for each model. The input-oriented one with the assumption of variable returns to scale was chosen, because the relative gap was the smallest in that model (it was non-existent $(0$ percent)). In other words, the optimum in this model is unique. Initial results of the optimization are given in Table 1, which shows that the maximum score was obtained in each quarter, and that the minimum score in each quarter ranges from 0.013 (12Q) to 0.274 (1Q). The last quarter was omitted due to the assumption that some or all of the most efficient stocks are bought at the end of the current quarter and held throughout the following one. Afterwards, these stocks are sold, and those which prove to be the most efficient in the following quarter are bought, and so on. Basically, the portfolio can be restructured each quarter.

Table 1: Score Results for Each Quarter

\begin{tabular}{l|c|c:c:c:c:c:c:c|c|c|c|c}
\hline Score & Q1 & Q2 & Q3 & Q4 & Q5 & Q6 & Q7 & Q8 & Q9 & Q10 & Q11 & Q12 \\
\hline Average & 0.7353 & 0.6131 & 0.5925 & 0.5691 & 0.5437 & 0.7662 & 0.676 & 0.6516 & 0.5573 & 0.5982 & 0.6009 & 0.5307 \\
\hline Max & 1 & 1 & 1 & 1 & 1 & 1 & 1 & 1 & 1 & 1 & 1 & 1 \\
\hline Min & 0.274 & 0.1558 & 0.1724 & 0.1307 & 0.0395 & 0.1635 & 0.1597 & 0.0965 & 0.0391 & 0.0405 & 0.0346 & 0.013 \\
\hline
\end{tabular}

Source: Author's calculations.

Table 2 presents stocks that were found relatively efficient ${ }^{15}$ in each observed quarter.

14 Based on Dumičić and Bahovec (2011).

15 Efficient in terms of DEA. 
Table 2: Results of the Analysis: Efficient Stocks by Quarter

\begin{tabular}{|c|c|c|c|c|c|c|c|c|c|c|c|}
\hline Q1 & Q2 & Q3 & Q4 & Q5 & Q6 & Q7 & Q8 & Q9 & Q10 & Q11 & Q12 \\
\hline & & & & & ZVCV & & ZVCV & & ZVCV & ZVCV & \\
\hline & VIRO & & VIRO & VIRO & VIRO & VIRO & VIRO & PBZ & PBZ & PBZ & \\
\hline ZVCV & PBZ & PODR & PBZ & PBZ & PBZ & PBZ & PBZ & PDBA & PODR & PODR & PODR \\
\hline PBZ & PDBA & SNHO & PDBA & PDBA & PDBA & PODR & PDBA & PODR & PTKM & PTKM & PTKM \\
\hline PODR & PODR & LEDO & PODR & PODR & PODR & SUNH & PODR & PTKM & PUNT & LEDO & JNAF \\
\hline PTKM & SNHO & BLSC & SNHO & SNHO & PUNT & KNZM & PTKM & SLRS & KNZM & JNAF & BLJE \\
\hline SUNH & KNZM & CKML & LEDO & KODT & LEDO & KOEI & SUNH & KOEI & KOEI & KNZM & CKML \\
\hline LKRI & CKML & ADRS & JNAF & KORF & LKRI & BLSC & KODT & BLJE & BLSC & BLJE & DDJH \\
\hline LRH & ADPL & ZVCV & KODT & ATLN & LRH & CKML & KORF & CKML & BLJE & CKML & ADPL \\
\hline \multirow[t]{5}{*}{ ADPL } & ADRS & PBZ & ZVCV & ZVCV & KNZM & ADPL & BLSC & DDJH & $\mathrm{DDJH}$ & $\mathrm{DDJH}$ & PBZ \\
\hline & ATLN & & & & KODT & & CKMI & ADRS & ADPL & ERNT & ZVCV \\
\hline & ZVCV & & & & KOEI & & DDJH & ZVCV & ADRS & ADPL & \\
\hline & & & & & KORF & & ERNT & & ATLN & ADRS & \\
\hline & & & & & ATLN & & & & & & \\
\hline
\end{tabular}

Source: Author's calculations.

Looking closer at Table 2 and Figure 2, three stocks were found to be overall efficient: ZVCV, PBZ and PODR.

Figure 2: Overall Score of Evaluated Stocks

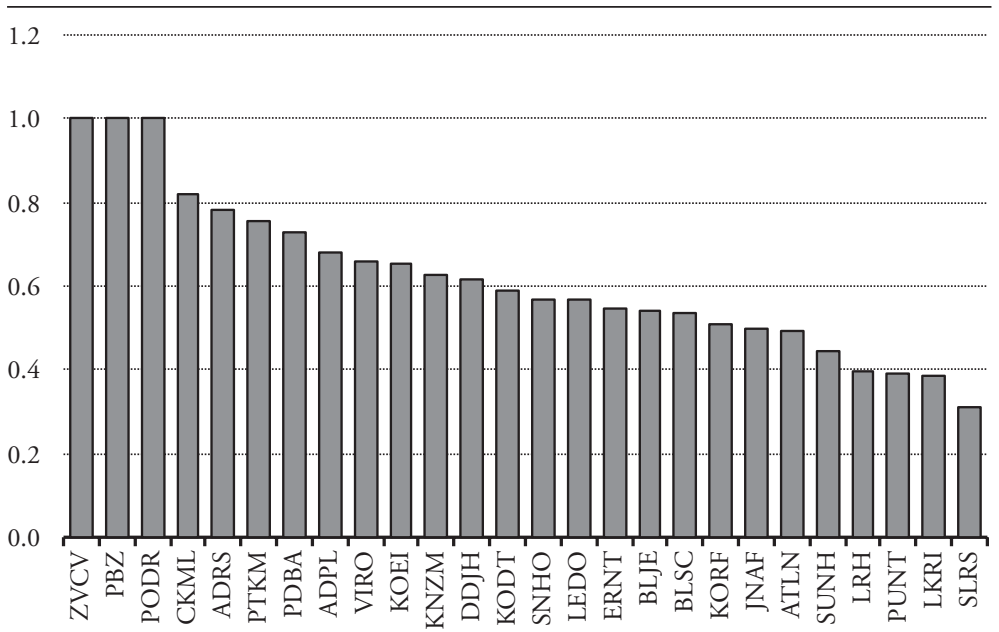

Source: Author's calculations. 
In order to evaluate the usefulness of the dynamic SBM model in portfolio management, several portfolios of these efficient stocks were formed in each quarter:

(i) The first portfolio was constructed as an equally weighted portfolio of all efficient stocks in each quarter - the simplest implementation of the results - and it will be called the sbm portfolio.

(ii) The second and third portfolios were constructed based on the Markowitz model (1952) for each period. Namely, the Markowitz optimization model was performed over each of the subgroups of stocks in each quarter (see Table 2). Two levels of risk were included: 1 percent (conservative investor) and 10 percent (aggressive investor) in each quarter. These portfolios will be called SBM_1\% and SBM_10\%, respectively.

(iii) The fourth portfolio was constructed as an equally weighted portfolio based on the three most efficient stocks (ZVCV, PBZ and PODR). Again, as the first one, this portfolio represents a simple implementation of the results from DEA, and it will be denoted as the 3best portfolio.

(iv) The fifth and sixth portfolios were constructed in a similar way as the second and third ones. The Markowitz optimization model was performed over the three most efficient stocks in each quarter. Again, two levels of risk were used, 1 percent and 10 percent. The two portfolios are named 3_BEST_1\% and 3_BEST_10\%, respectively.

All of the mentioned portfolios will be evaluated in relation to the market portfolio, first without and then with included transaction costs.

\subsection{Analysis without Transaction Costs}

In order to evaluate the performance of the DEA portfolios, an approximation of the market portfolio return was made using the Croatian stock index CROBEX. Average returns on the two simple portfolios ( $s b m$ and 3best), as well as the 
return on CROBEX are shown in Figure 3. As can be seen, the return of the 3best portfolio (full line) is the biggest since it predominantly outperformed the market with positive return in each quarter. Therefore, using skewness as a good link proved to be a good indicator of the desirability of the observed stocks. The sbm portfolio's return (dashed line) outperformed the market in 6 out of 12 quarters. Still, the overall result of this portfolio is better than the market (in terms of the average return realized over the whole observed period). Finally, it can be seen that the return on CROBEX (dotted line) was the smallest in some of the quarters, but the realized loss was also rather small in comparison with the sbm portfolio in, e.g., 10Q. If we examine the volatility of the returns, it is obvious that the market portfolio and the 3best portfolio returns have smaller volatility than the sbm portfolio return.

Figure 3: Returns on Market Portfolio, 3best Portfolio and sbm Portfolio

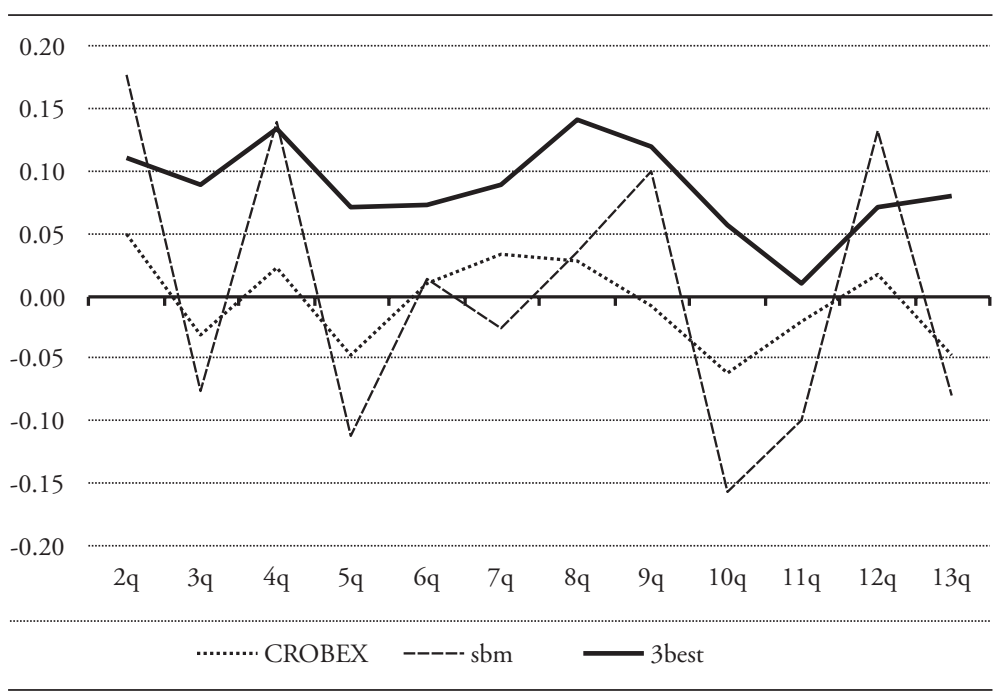

Source: Author's calculations.

Next, it is useful to observe the ratio of the realized return and risk (standard deviation), i.e., the return realized on unit risk. This has been done in order to 
compare the levels of return on each portfolio with regard to the same level of risk. In that way, the investor seeks to maximize the return on a given level of risk (which is in accordance with Markowitz's portfolio theory). Thus, we standardize different rates of return on different risk levels by using the risk itself. The bigger the standardized return, the better the portfolio has performed. Figure 4 shows the results. It can be seen that the 3best portfolio outperformed the other two portfolios in almost every quarter (except the twelfth one). The market portfolio did the worst. Again, this has proven that using the dynamic SBM model can be useful in detecting the most desirable components of the portfolio.

\section{Figure 4: Standardized Returns on Market Portfolio, 3best Portfolio and sbm Portfolio}

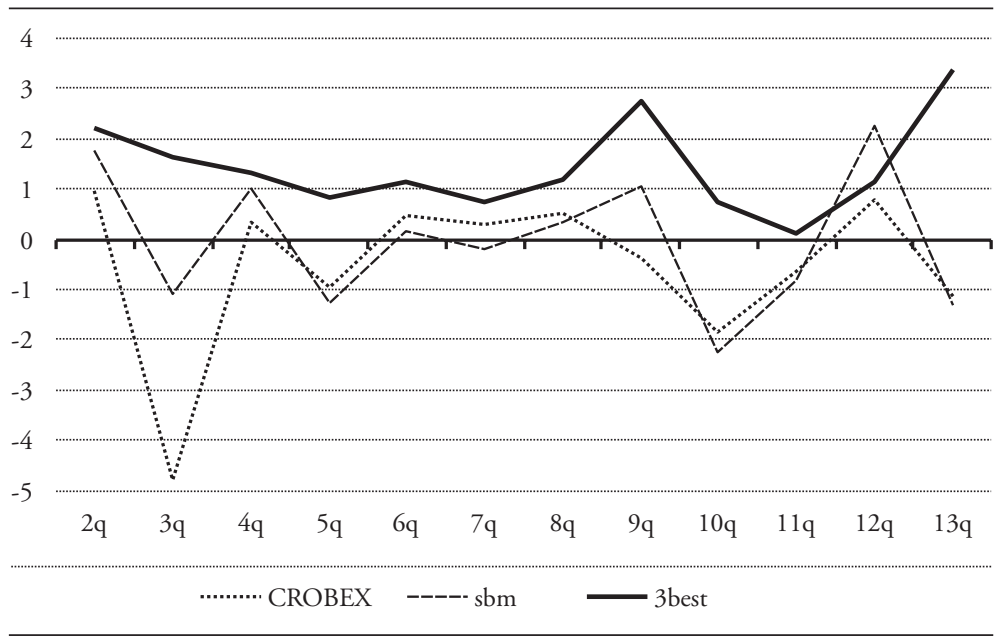

Source: Author's calculations.

Figure 5 gives an overview of the cumulative returns for all three portfolios. They have been calculated based on the assumption of investing one Croatian kuna (HRK). The 3best portfolio has resulted in outstanding performance since the initial investment has almost tripled. Although the $s b m$ portfolio had a good start, at the end of the period the earned cumulative return started to melt, and in the end dropped below the invested one HRK. Finally, the cumulated market 
return did the worst. In fact, it was barely above the invested one HRK during the whole time, until a negative trend in the third part of the period.

Figure 5: Cumulated Returns on All Three Portfolios

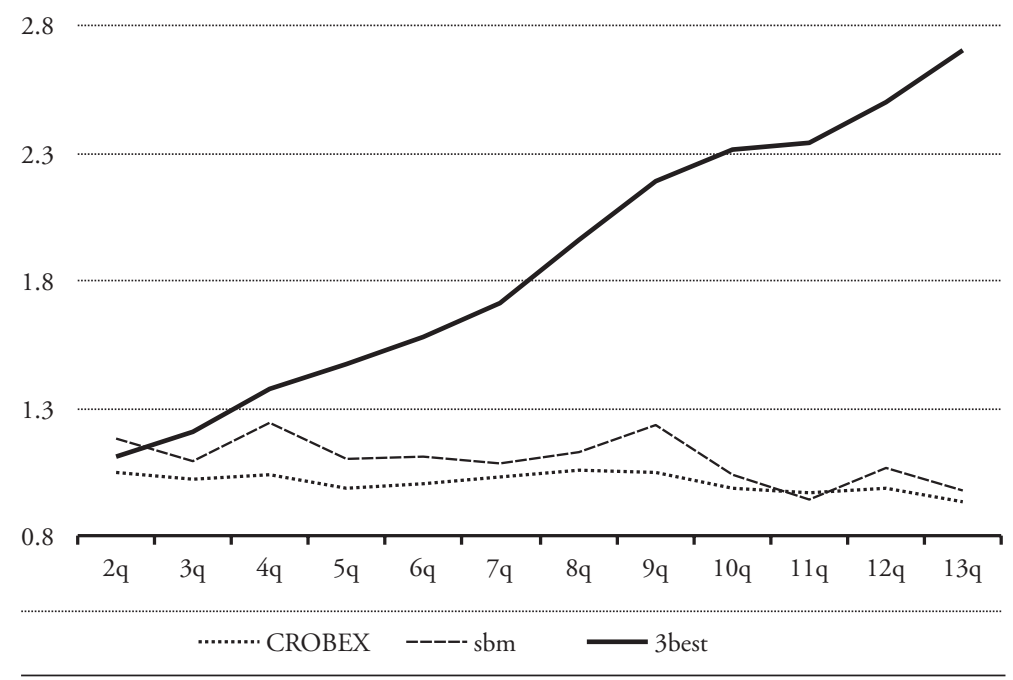

Source: Author's calculations.

In order to employ MPT, Markowitz models were optimized which resulted in the following portfolios: SBM_1\%, SBM_10\%, 3_BEST_1\% and 3_BEST_10\%. Figure 6 shows the returns on each of these portfolios. The 3best (black full line) and $S B M_{-} 10 \%$ (gray full line) portfolios are the best in terms of the realized return, with the 3best portfolio having greater return in 7 out of 12 quarters. 3_BEST_1\% and CROBEX did the worst; both of these portfolios realized the lowest returns (even losses) in the observed period.

In order to compare the risk and return of each of the portfolios, standardized returns were calculated. In this way, investors can choose the most efficient portfolio in terms of MPT - maximizing the return on a given level of risk. The results are given in Figure 7. Once again, the 3best and SBM_10\% portfolios are the best in terms of realized returns. 
Figure 6: Returns on Market Portfolio, 3best, sbm, SBM_1\%, SBM_10\%, 3_BEST_1\% and 3_BEST_10\% Portfolio

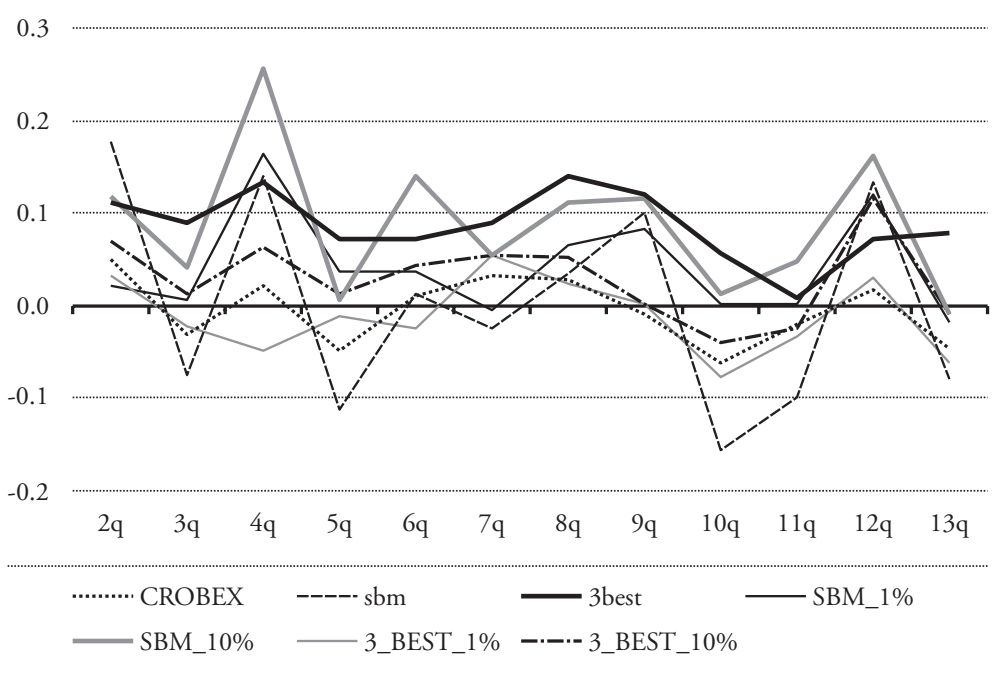

Source: Author's calculations.

Figure 7: Standardized Returns on Market Portfolio, 3best, sbm, SBM_1\%, SBM_10\%, 3_BEST_1\% and 3_BEST_10\% Portfolio

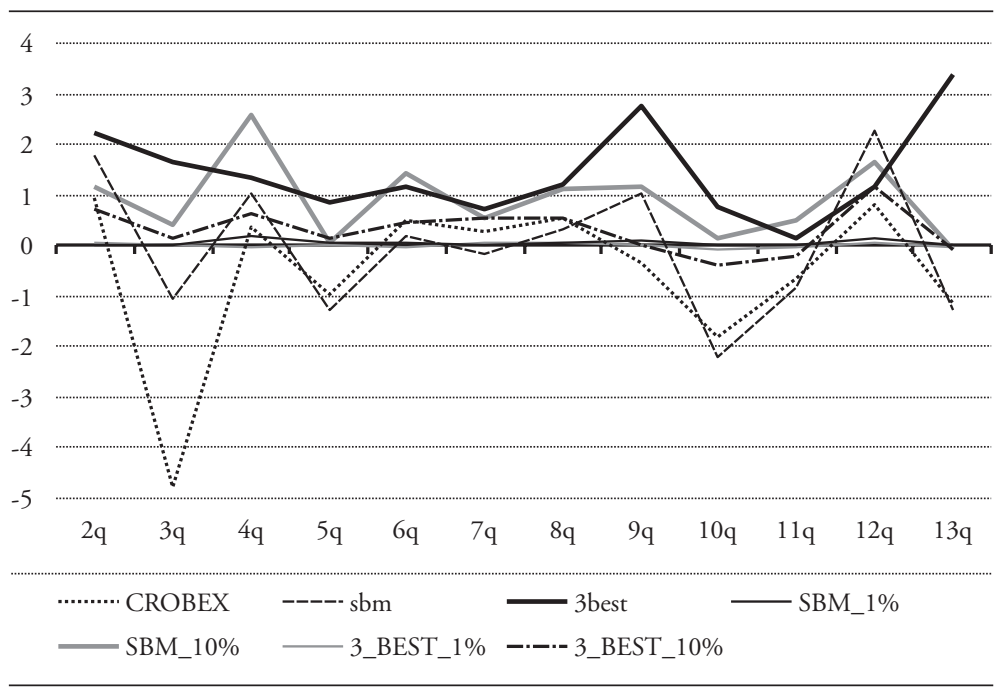

Source: Author's calculations. 
Finally, some descriptive statistics on returns and risk were examined for all portfolios for the whole period. On average, a market portfolio realized a loss of 0.49 percent. The SBM_10\% and 3best portfolios realized the greatest returns, 8.8 percent and 8.69 percent, respectively. This is a substantial difference. Looking at the standard deviation as a measure of risk, the most volatile portfolios are the ones which were optimized in a Markowitz framework (10 percent). By comparing the unit risk return, it is obvious that investors would choose the 3 best portfolio, due to the largest reward-risk ratio. Thus, a conclusion can be made: in the analyzed case, the dynamic DEA-based portfolio yielded better results than the market one and Markowitz-based ones. The reason for this superiority lies in the dynamic structure of the SBM methodology as has already been explained.

Table 3: Descriptive Statistics for All Portfolios

\begin{tabular}{l|c|c:c:c:c:c:c}
\hline & CROBEX & sbm & SBM_10\% & SBM_1\% & 3best & 3_BEST_1\% 3_BEST_10\% \\
\hline Mean & $-0,0049$ & 0,0038 & 0,0880 & 0,0429 & 0,0869 & $-0,0116$ & 0,0297 \\
Median & 0,0009 & $-0,0061$ & 0,0828 & 0,0288 & 0,0840 & $-0,0170$ & 0,0284 \\
Maximum & 0,0491 & 0,1774 & 0,2570 & 0,1631 & 0,1399 & 0,0536 & 0,1165 \\
Minimum & $-0,0616$ & $-0,1572$ & $-0,0094$ & $-0,0172$ & 0,0094 & $-0,0780$ & $-0,0400$ \\
Std. Dev. & 0,0431 & 0,0934 & 0,1000 & 0,0100 & 0,0727 & 0,0100 & 0,1000 \\
Mean/Std. Dev. & $-0,5344$ & $-0,0316$ & 0,8802 & 0,0429 & 1,4400 & $-0,0116$ & 0,2969 \\
\hline
\end{tabular}

Source: Author's calculations.

\subsection{Analysis with Transaction Costs}

Economic analysis often neglects transaction costs. In real life, however, it is not possible to ignore them, especially when the results of the analysis can differ significantly. When trading on the stock market, investors deal with transaction costs. In Croatia, transaction costs include costs of participation on the Zagreb Stock Exchange:

(i) 0.08 percent on amounts up to HRK 6 million of daily turnover,

(ii) 0.06 percent on amounts ranging from over HRK 6 million to HRK 20 million,

(iii) 0.02 percent on amounts bigger than HRK 20 million (ZSE, 2014). 
The Central Depository and Clearing Company (CDCC) also requests a compensation for handling records on stocks (and other financial assets). Mediators (such as banks and brokerage firms) charge brokerage fees regardless of the type of stock trade - conducted via the Internet, telephone, etc. Some of the mediators' fees are presented in Table 4. As can be seen, trading over the Internet is usually the cheapest. The last column gives an overview of all transaction costs included (ZSE and CDCC as well).

Table 4: Selected Mediators in Stock Trading: Fees Based on HRK 1 Million Transaction

\begin{tabular}{|c|c|c|c|c|c|}
\hline \multirow[b]{2}{*}{ Mediator } & \multicolumn{2}{|c|}{ Minimal fee $(\mathrm{HRK})$} & \multicolumn{2}{|c|}{ Fee on each transaction (in \%) } & \multirow{2}{*}{$\begin{array}{c}\text { Fees } \\
\text { included }\end{array}$} \\
\hline & $\begin{array}{c}\text { Internet } \\
\text { trade }\end{array}$ & $\begin{array}{c}\text { Other forms } \\
\text { of trade }\end{array}$ & $\begin{array}{c}\text { Internet } \\
\text { trade }\end{array}$ & $\begin{array}{c}\text { Other forms } \\
\text { of trade }\end{array}$ & \\
\hline Hita vrijednosnice & 10 & 100 & 0.5 & negotiable & all fees \\
\hline Agram brokeri & 0 & 150 & 0.3 & 0.7 & not indicated \\
\hline Aktiv broker & 50 & 100 & 0.5 & 1 & not indicated \\
\hline Splitska banka & 60 & 100 & 0.5 & 0.6 & all fees \\
\hline $\begin{array}{l}\text { Banka splitsko } \\
\text { dalmatinska }\end{array}$ & \multicolumn{2}{|c|}{ not stated } & 0.24 & 0.35 & not included \\
\hline OTP banka & not stated & 100 & 0.5 & 0.5 & not included \\
\hline $\mathrm{HPB}$ & not stated & 80 & 0.4 & 0.4 & not indicated \\
\hline Ilirika & 60 & 120 & 0.5 & 1 & all fees \\
\hline Podravska banka & 100 & 100 & 0.68 & 0.68 & all fees \\
\hline Raiffeisen banka & 30 & 150 & 0.3 & 0.7 & all fees \\
\hline
\end{tabular}

Source: Škrinjarić (2013b: 102).

In this paper it is assumed that investors aim to minimize the transaction costs, so an arbitrary level of transaction costs of 0.3 percent will be calculated in all of the simulated transactions. The analysis was also done based on 1 percent and 10 percent cost assumption, ${ }^{16}$ but the only difference arising from different levels of transaction costs is that all of the portfolio returns shift parallelly upwards or downwards, depending on whether the cost is lower or higher when compared to the initial percentage.

16 The results of the analysis with 1 percent and 10 percent cost assumption are given in the Appendix. 
The results of the analysis with transaction costs are given in Figure 8. When compared to Figure 6, the difference is barely noticeable, but all of the lines have shifted downwards. The conclusion remains the same as for Figure 6 .

Figure 8: Returns on Market Portfolio, 3best, sbm, SBM_1\%, SBM_10\% Portfolio: $0.3 \%$ Transaction Costs

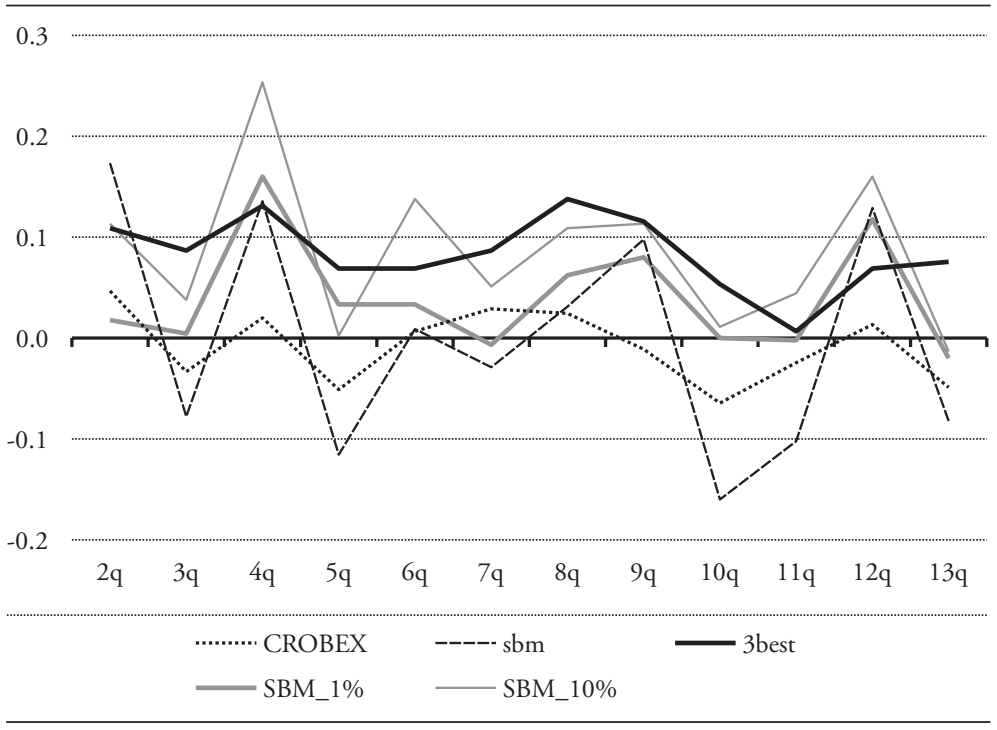

Source: Author's calculations.

Furthermore, cumulated earnings were calculated based on the whole analyzed period (Figure 9). If the investor had formed the 3best or SBM_10\% portfolio, s/ he would have gained substantial rewards. The calculations were rescaled based on one HRK invested, and it can be seen that the two mentioned portfolios gained approximately one HRK. The market portfolio, as well as the 3_BEST_1\% one, did the worst. 
Figure 9: Cumulated Earnings on All Portfolios: 0.3\% Transaction Costs

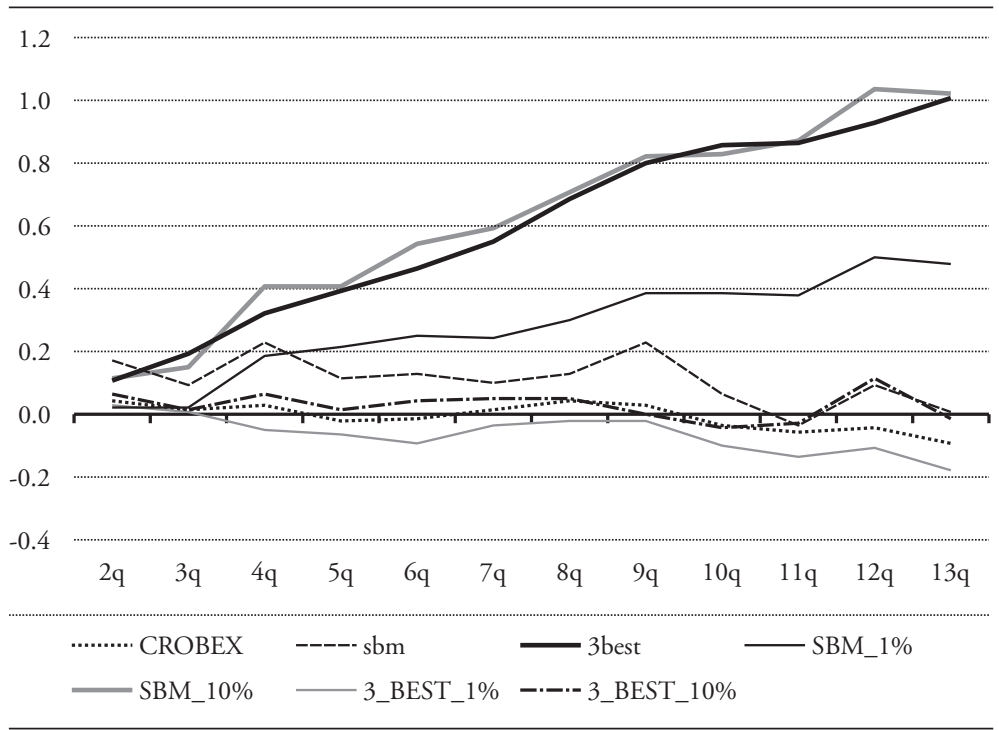

Source: Author's calculations.

\section{Conclusion}

Outperforming the market is one of the primary goals of every investor. During the past decades, different investment strategies have been developed, using mathematical, econometric, statistical and other methods and models as guidelines for choosing the "optimal" financial instruments, time and other relevant variables. This paper investigates the possible potential of nonparametric methods for evaluating stocks and managing portfolios. Specifically, a dynamic SBM model was used to evaluate the relative efficiency of stocks on the Zagreb Stock Exchange. The contribution of the model employed in this study is reflected in the possibility of portfolio rebalancing in each sub-period based on the results of relative efficiency in each sub-period. In that way, the constructed portfolio has better properties in terms of return and risk when compared to basic DEA portfolios. 
Following the outcomes of the optimization, some of the resulting portfolios realized greater (standardized) returns than the market return, and the findings proved that using Data Envelopment Analysis can be very helpful in detecting efficient stocks to invest in, in terms of return and risk. The coefficient of skewness of each stock return was used as a good link in determining when above-average returns are more likely to occur. In that way, the portfolios were predisposed to perform with above-average returns in each period which resulted in returns much greater than the market portfolio.

However, there are some limitations of the research. A relatively small number of stocks were included in the evaluation. The Zagreb Stock Exchange is not a very liquid market, so there are some difficulties with data on stocks. Furthermore, the analysis has been done over monthly and quarterly data, which do not necessarily reflect the intra-month oscillations. Future work could include the analysis of weekly data which could overcome this limitation. Future research might extend the initial model to other measures of risk (the beta coefficient, VaR measures) and the fourth moment of distributions (the coefficient of kurtosis). Moreover, daily and weekly data can be observed in order to be compared with the results of this paper. The question remains whether the results of this methodology can be compared to other portfolios which result from other methods and models. It is advisable to be careful when comparing the results of different methodologies, due to the differences in the assumptions regarding data and relationships between the variables. This is why empirical studies regularly do not compare the results of different methodologies. Future work could compare portfolios which result from the dynamic DEA model, but with different relevant inputs, outputs and link variables.

Due to the availability of the data, as well as the technical abilities of today's computers to optimize different models, there is hope that such analysis will be more frequent and more relevant in the future. 


\section{Appendix}

Figure A1: Returns on Market Portfolio, 3best, sbm, SBM_1\%, SBM_10\%, 3_BEST_1\% and 3_BEST_10\% Portfolio: 1\% Transaction Costs

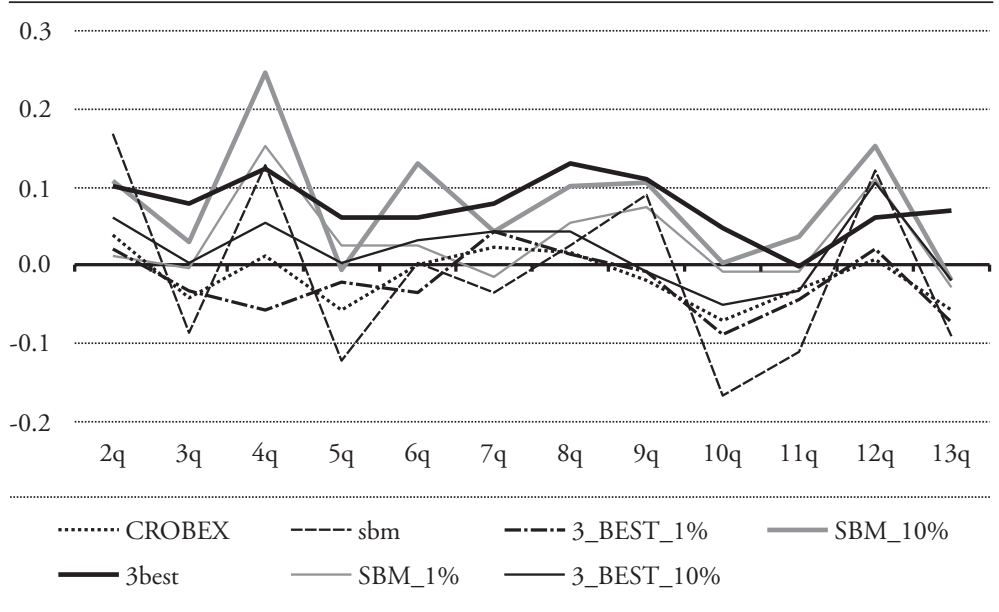

Source: Author's calculations.

Figure A2: Cumulated Earnings on All Portfolios: 1\% Transaction Costs

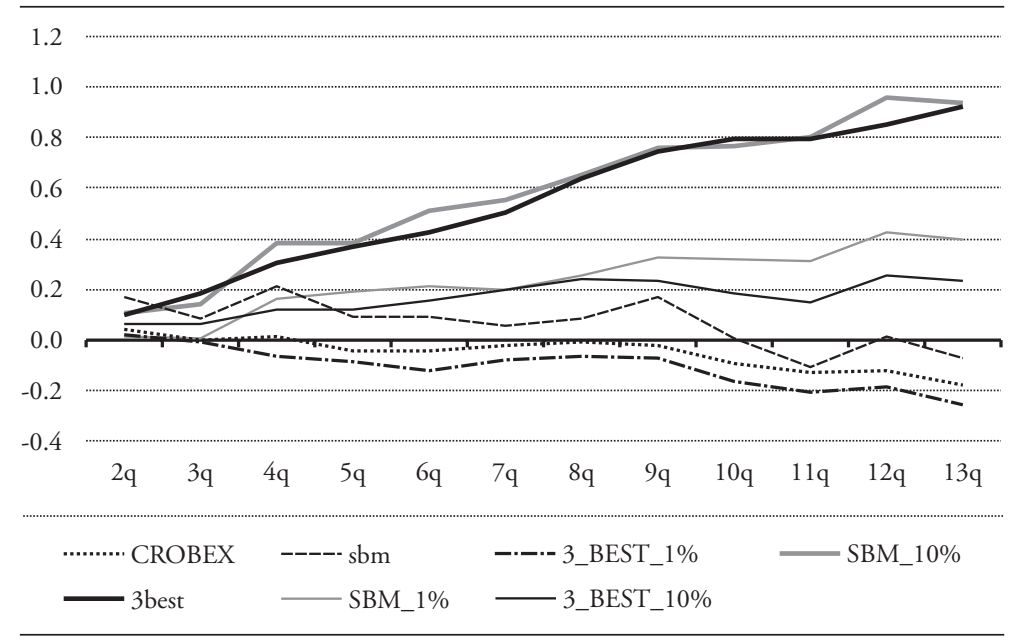

Source: Author's calculations. 
Figure A3: Returns on Market Portfolio, 3best, sbm, SBM_1\%, SBM_10\%, 3_BEST_1\% and 3_BEST_10\% Portfolio: $10 \%$ Transaction Costs

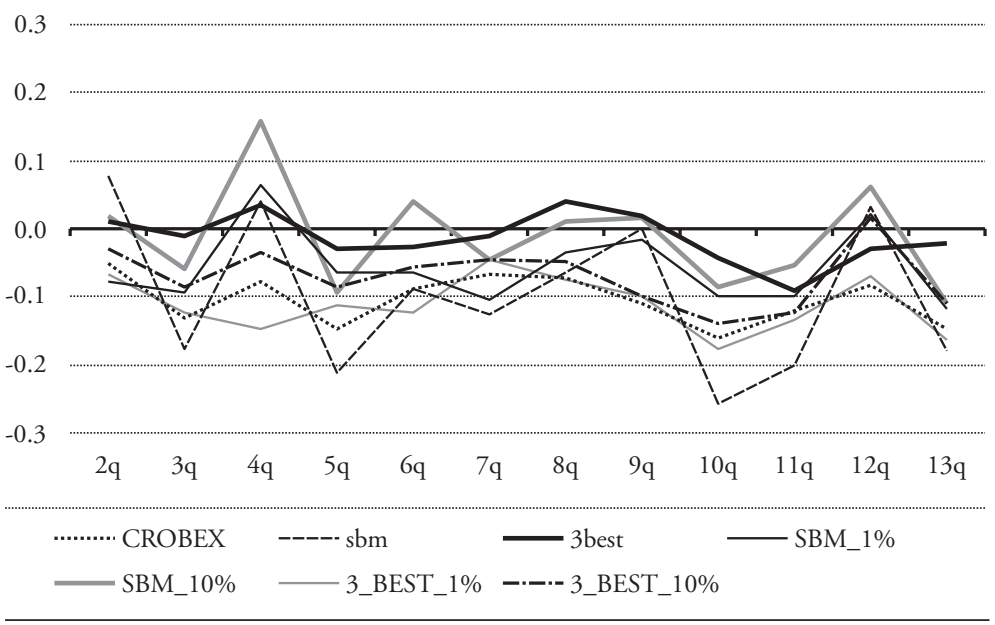

Source: Author's calculations.

Figure A4: Cumulated Earnings on All Portfolios: 10\% Transaction Costs

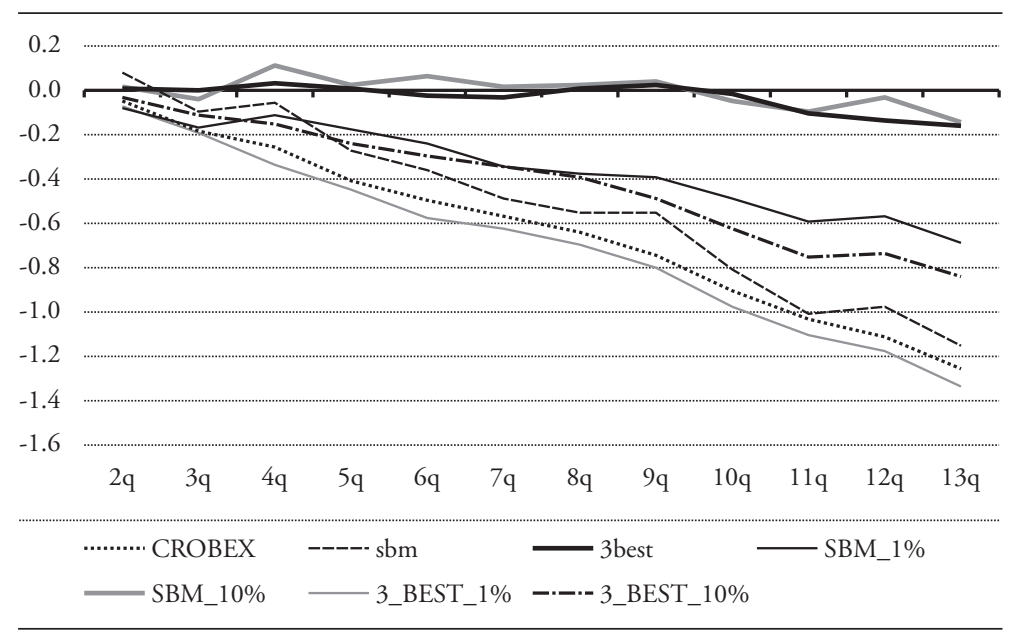

Source: Author's calculations. 


\section{Literature}

Adcock, Chris J., 2005, "Exploiting skewness to build an optimal hedge fund with a currency overlay", European Journal of Finance, 11(5), pp. 445-462. http:// dx.doi.org/10.1080/13518470500039527

Alderfer, Clayton P. and Harold Bierman, 1970, "Choices with Risk: Beyond the Mean and Variance", Journal of Business, 43(3), pp. 341-353. http://dx.doi. org/10.1086/295286

Arditti, Fred, 1967, "Risk and the Required Return on Equity", Journal of Finance, 22(1), pp. 19-36. http://dx.doi.org/10.1111/j.1540-6261.1967.tb01651.x

Athayde, Gustavo and Renato Flores, 2004, "Finding a Maximum Skewness Portfolio: A General Solution to Three-Moments Portfolio Choice", Journal of Economic Dynamics \& Control, 28(7), pp. 1335-1352. http://dx.doi.org/10.1016/ S0165-1889(02)00084-2

Barbić, Tajana and Iva Čondić-Jurkić, 2011, "Povezanost između makroekonomskih varijabli i burzovnih indeksa u odabranim zemljama Srednje i Istočne Europe”, Ekonomski pregled, 62(3-4), pp. 113-133.

Benazić, Manuel, 2008, "Povezanost cijene dionica i deviznog tečaja u Republici Hrvatskoj: VEC model”, Ekonomski pregled, 59(11), pp. 669-687.

Briš, Martina, Ivan Kristek and Ivo Mijoč, 2008, "Selection of optimal portfolio by use of risk diversification method" in Dražen Barković and Bodo Runzheimer, eds., Interdisciplinary Management Research IV, pp. 329-343, Osijek: Faculty of Economics and Pforzheim: Hochschule Pforzheim, University of Applied Sciences.

Charnes, Abraham, William Wager Cooper and Edwardo L. Rhodes, 1978, "Measuring the efficiency of decision making units", European Journal of Operational Research, 2(6), pp. 429-444. http://dx.doi.org/10.1016/03772217(78)90138-8 
Chen, Hsin-Hung, 2008, "Stock selection using data envelopment analysis", Industrial Management \& Data Systems, 108(9), pp. 1255-1268. http://dx.doi. org/10.1108/02635570810914928

Cooper, William Wager, Lawrence M. Seiford and Joe Zhu, 2004, Handbook on Data Envelopment Analysis, Boston, MA: Kluwer Academic Publishers.

Costa, Edward, Francisco Ramos and Hemino Souza, 2012, "The productive efficiency of federal institutions of Brazilian higher education", paper presented at the "10th International Conference on Data Envelopment Analysis" organized by iDEAs, Natal, Brazil, August 27-30.

Dumičić, Ksenija and Vlasta Bahovec, eds., 2011, Poslovna statistika, Zagreb: Element d.o.o.

Fabac, Robert and Dušan Munđar, 2011, "Optimization of Portfolio of Stocks at ZSE through the Analysis of Historical Data", Computer Technology and Application, 2(12), pp. 1007-1014.

Fama, Eugene Francis, 1965, "The Behaviour of Stock Market Prices", Journal of Business, 38(1), pp. 34-105.

Färe, Rolf and Shawna Grosskopf, 1996, Intertemporal Production Frontiers: With Dynamic DEA, New York, NY: Springer.

Färe, Rolf, Shawna Grosskopf, Mary Norris and Zhongyang Zhang, 1994, "Productivity growth, technical progress, and efficiency change in industrialized countries", American Economic Review 84(1), pp. 66-83.

Gardijan, Margareta and Vedran Kojić, 2012, "DEA-based investment strategy and its application in the Croatian stock market", Croatian Operational Research Review, 3(1), pp. 203-212. 
Graddy, Duane and Ghassem Homaifar, 1988, "Equity Yields in Models Considering Higher Moments of the Return Distribution", Applied Economics, 20(3), pp. 325-334.

Hsing, Yu, 2011, "Macroeconomic variables and the stock market: the case of Croatia”, Ekonomska istraživanja, 24(4), pp. 41-50.

Jakšić, Saša, 2007, "Primjena Markowitzeve teorije na tržište dionica Zagrebačke burze”, Zbornik Ekonomskog fakulteta u Zagrebu, 5(1), pp. 331-344.

Jerončić, Marko and Zdravka Aljinović, 2011, "Formiranje optimalnog portfelja pomoću Markowitzevog modela uz sektorsku podjelu kompanija”, Ekonomski pregled, 62(9-10), pp. 583-606.

Jondeau, Eric and Michael Rockinger, 2003, "How Higher Moments Affect the Allocation of Assets", Finance Letters, 1(2), pp. 1-5,

Klopp, Gerald A., 1985, "The analysis of the efficiency of productive systems with multiple inputs and outputs", PhD dissertation, Chicago, IL: University of Illinois, Industrial and System Engineering College.

Lopes, Ana, Edgar Lanzer, Marcus Lima and Newton da Costa, Jr., 2008, "DEA investment strategy in the Brazilian stock market”, Economics Bulletin, 13(2), pp. 1-10.

Mandelbrot, Benoit, 1963, “The Variation of Certain Speculative Prices”, Journal of Business, 36(4), pp. 394-419. http://dx.doi.org/10.1086/294632

Marasović, Branka, Tea Poklepović and Zdravka Aljinović, 2011, "Markowitz' Model with Fundamental and Technical Analysis - Complementary Methods or Not”, Croatian Operational Research Review (CRORR), 2(1), pp. 122-132.

Marasović, Branka and Boško Šego, 2006, "Markowitzev model optimizacije portfelja”, Računovodstvo i financije, 52(6), pp. 57-61. 
Markowitz, Harry, 1952, "Portfolio Selection", The Journal of Finance, 7(1), pp. 77-91. http://dx.doi.org/10.1111/j.1540-6261.1952.tb01525.x

Müller, Sigrid and Mark Machina, 1987, "Moment preferences and polynomial utility”, Economics Letters, 23(4), pp. 349-353. http://dx.doi.org/10.1016/01651765(87)90143-1

Neralić, Luka, 1996, "O nekim primjenama analize omeđivanja podataka u bankarstvu”, Ekonomija, 2(3), pp. 493-521.

Pätäri, Eero J., Timo H. Leivo and J.V. Samuli Honkapuro, 2010, "Enhancement of value portfolio performance using data envelopment analysis" Studies in Economics and Finance, 27(3), pp. 223-246. http://dx.doi.org/10.1108/10867371011060036

Powers, Jennifer and Patrick McMullen, 2002, "Using data envelopment analysis to select efficient large cap securities", Journal of Business and Management, 7(7), pp. 31-42.

Rabar, Danijela, 2010, "Ocjenjivanje efikasnosti poslovanja hrvatskih bolnica metodom analize omeđivanja podataka”, Ekonomski pregled, 61(9-10), pp. 511533.

Rubinstein, Mark, 1973, "The Fundamental Theorem of Parameter-preference Security Valuation", Journal of Financial and Quantitative Analysis, 8(1), pp. 6169. http://dx.doi.org/10.2307/2329748

Samuelson, Paul, 1970, "The Fundamental Approximation Theorem of Portfolio Analysis in Terms of Means, Variances and Higher Moments", Review of Economic Studies, 37(4), pp. 537-542. http://dx.doi.org/10.2307/2296483

Šegota, Alemka, 2008, "Evaluating shops efficiency using data envelopment analysis: Categorical approach", Zbornik radova Ekonomskog fakulteta u Rijeci, 26(2), pp. 195-212. 
Škrinjarić, Tihana, 2013a, "Portfolio Selection with Higher Moments and Application on Zagreb Stock Exchange", Zagreb International Review of Economics and Business, 16(1), pp. 65-78.

Škrinjarić, Tihana, 2013b, "Investicijske strategije prilagođene dnevnoj sezonalnosti u prinosima dionica", Ekonomska misao i praksa, 2013(1), pp. 97120.

Tone, Kaoru and Miki Tsutsui, 2010, "Dynamic DEA: A slacks-based measure approach", Omega, Vol. 38(3-4), pp. 145-156. http://dx.doi.org/10.1016/j. omega.2009.07.003

Vizek, Maruška and Tajana Dadić, 2006, "Integracija tržišta kapitala Hrvatske, zemalja Srednje i Istočne Europe i Europske Unije: kointegracijski pristup“, Ekonomski pregled, 57(9-10), pp. 631-646.

Zagreb Stock Exchange, 2012, http://www.zse.hr (accessed September 1, 2012). ZSE, 2001, Review of trade in 2000, http://zse.hr/default.aspx?id=178\&yr=2000 (accessed February 15, 2014).

ZSE, 2014, Review of trade in 2013, http://zse.hr/default.aspx?id=178\&yr=2013 (accessed February 15, 2014). 